\title{
Я.М. ЖУКОРСЬКА
}

\author{
Ярина Михайлівна Жукорська, кандидат юридич- \\ них наук, доцент, доцент Західноукраїнського \\ національного університету*
}

ORCID: 0000-0002-7797-5207

\section{ІСТОРІЯ ВИНИКНЕННЯ ТА СТАНОВЛЕННЯ МИРОТВОРЧОЇ ДІЯЛЬНОСТІ ООН}

Постановка проблеми. У сучасному світі є багато загроз, з якими варто боротися не індивідуально, а колективно - спільними зусиллями. Особливо важливим є використання колективних зусиль задля підтримки миру та безпеки, адже далеко не кожна держава може впоратися з цим самотужки. Звідси - прагнення держав вступати у міжнародні безпекові організації. Однією з найвагоміших організацій, яка здійснює свою діяльність в сфері безпеки, є Організація Об'єднаних Націй (далі - ООН). Однією з основних цілей ООН згідно 3 п. 1 ст. 1 є «підтримання міжнародного миру і безпеки» ${ }^{1}$. А одним із інструментів досягнення цієї цілі - миротворчі сили ООН.

Аналіз останніх досліджень і публікацій. Діяльність миротворчих сил ООН за всю їхню історію викликала як схвалення, так і заперечення, а також багато суперечок. Дослідженням питань діяльності миротворчих сил займалися такі вчені, як Р. Атто, П. Вільямс, Й. Купс, Н. Макквін, М. Нагді, М. Розес, А. Сміт, Т. Тарді, Ю. Запарій, О. Ковтун, О. Кресін, Я. Матсуда, О. Мережко, М. Неліп, Л. Ромадан, А. Рубцова, О. Стойко, Т. Финдлей та інші. В українській науці міжнародного права немає комплексного дослідження діяльності миротворчих місій ООН, хоча окремі питання аналізувалися достатньо глибоко. Серед останніх публікацій варто виділити наукову записку «Політико-правові засади миротворчої операції в Донбасі: світовий досвід для України» О. Кресіна, І. Проценко, К. Савчука. та О. Стойко 2018 р., у якій проаналізовано міжнародно-правові аспекти миротворчості, правове регулювання миротворчої діяльності ООН, механізми їі ініціювання, здійснення, фінансування, інституційні особливості ухвалення рішень ООН щодо проведення миротворчих операцій, визначено види миротворчих операцій, їх принципи, критерії, класифікацію, нормативно-правові засади співпраці ООН у цій сфері з регіональними та субрегіональними організаціями.

Формулювання мети статті. Мета статті - дослідити історію виникнення та становлення миротворчих місій ООН, а також їх ефективності протягом усього періоду існування.

Виклад основного матеріалу. Першими двома офіційними місіями ООН, які поклали початок миротворчій діяльності ООН, були Орган Організації Об’єднаних Націй зі спостереження за виконанням умов перемир'я між Ізраїлем та сусідніми арабськими державами (United Nations Truce Supervision Organization) i Група воєнних спостерігачів ООН в Індії та Пакистані (United Nations Military Observer Group in India and Pakistan).

Миротворча ж діяльність ООН у традиційному її розумінні з'явилася у той час, коли протистояння сторін у холодній війні паралізувало діяльність Ради Безпеки - у 1956 р. під час Суецької кризи.

Для того, щоб розуміти, як еволюціонувала миротворча діяльність від моменту появи і до сьогоднішнього дня, а також, щоб мати змогу оцінити, як зростала їі ефективність, історію миротворчих місій доречно поділити на такі періоди:

- 1948-1956 pр. - від створення першого контингенту воєнних спостерігачів на Близькому Сході до Суецької кризи;

- 1956-1988 рр. - від створення першої миротворчої місії ООН з розділення воюючих сторін, т.зв. Перших надзвичайних військових сил ООН, до кінця «холодної війни»;

- 1989-1999 рр. - від створення трьох нових місій у Анголі, Намібії та Центральній Америці до кризи в миротворчій діяльності після місії в Сомалі та Югославії;

- 1999-2020 рр. - від відновлення миротворчої діяльності після кризи, починаючи з місії у Косово, і до сьогоднішнього дня.

Миротворча діяльність ООН починає свій відлік із 1948 р., коли Рада Безпеки ООН санкціонувала розгортання контингенту воєнних спостерігачів ООН на Близькому Сході. Було створено Орган Організації Об'єднаних Націй зі спостереження за виконанням умов перемир'я, який мав здійснювати контроль за виконанням Угоди про перемир'я між Ізраїлем та сусідніми арабськими державами 2,3,4.

Вона виявилася неефективною як миротворча місія, але успішною як спостережна. Спостерігачі, що входять до цієї місії, знаходяться на Близькому Сході і сьогодні з метою спостереження та нагляду за припиненням вогню, контролю за дотриманням умов перемир'я, попередження ескалації окремих інцидентів і

(C) Я.М. Жукорська, 2020

* Yaryna Zhukorska, Ph.D. in Law, Associate Professor, Associate Professor of West Ukrainian National University 
надання допомоги іншим операціям ООН з підтримки миру в даному регіоні у виконанні їх мандату. Крім того, персонал місії дає можливість в дуже короткі строки сформувати ядро інших операцій $з$ підтримання миру в будь-якому куточку світу. Фактично, вони працюють як група швидкого реагування, що дає можливість забезпечити розгортання воєнних спостерігачів відразу після рішення РБ про надання повноважень новій місії, а час має вирішальний характер для успішного проведення таких операцій 5 .

У 1948 р. Рада Безпеки прийняла резолюцію 39, якою було започатковано Комісію РБ ООН по Індії та Пакистану (UNCIP), що стали гарячою точкою у 1947 р., відразу після здобуття незалежності. Мирний договір між цими двома державами, підписаний у 1949 р. в Карачі, передбачав направлення в регіон спостерігачів UNCIP. Перша група спостерігачів прибула 24 січня 1949 р. з метою спостереження за припиненням вогню між Індією та Пакистаном у штатах Кашмір та Джамму. Саме вони стали ядром Групи воєнних спостерігачів ООН в Індії та Пакистані. Після відновлення воєнних дій у 1971 р. вони залишилися в регіоні $з$ метою спостереження за розвитком подій, пов'язаних з дотриманням договору про припинення вогню від 17 грудня 1971 р., та надання відповідних доповідей Генеральному секретарю6.

Санкціонована кількість цих двох спостережних місій не перевищувала кількасот чоловік, до їх складу входили неозброєні військові спостерігачі та легко озброєні військовослужбовці, які виконували здебільшого функції спостереження, підготовки доповідей і здійснення заходів із зміцнення довіри.

Спостережна місія виявилася неефективною щодо попередження порушення умов перемир'я, особливо в умовах Суецької кризи 1956 р. Держави-члени Ради Безпеки також не змогли прийняти рішення щодо організації миротворчої місії для врегулювання цього конфлікту, адже участь у ньому брали Великобританія та Франція, які є постійними членами РБ ООН, і блокували рішення7.

У цих умовах вирішення конфлікту було можливим лише за межами РБ ООН, і Генеральний секретар Даг Хаммершельд за порадою міністра закордонних справ Канади Лестера Пірсона прийняв рішення створити міжнародні надзвичайні збройні сили, які будуть формуватися з військовослужбовців держав-тимчасових членів РБ, що давало змогу вирішити проблему з можливістю ветування рішення РБ ії постійними державами-членами, які були сторонами конфлікту або заінтересованими сторонами. Миротвочість мала базуватися на трьох основних принципах - згода держави-члена ООН, яка є стороною конфлікту; неупередженість; незастосування сили, окрім випадку самооборони ${ }^{8}$. Дислокуватися такі збройні сили мали між сторонами противника, в даній ситуації між військами Єгипту та Ізраїлю9.

Рекомендації Д. Хамершельда лягли в основу Резолюції 1000 Генеральної Асамблеї ООН, згідно з якою було створено міжнародні миротворчі збройні сили під командування канадського генерал-майора Е. Бернса ${ }^{10}$. Це, фактично, була перша офіційна миротворча місія ООН, метою якої стало розділення воюючих сторін ${ }^{11}$. Принципи діяльності місії розроблялися Д. Хамершельдом 3 нуля, адже при Лізі Націй схожих місій не було, а діяльність спостережних місій типу UNTSO грунтувалася зовсім на інших засадах ${ }^{12}$. Тут варто звернути увагу, що саме Генеральні секретарі ООН з цього моменту і в майбутньому відігравали велику роль у здійснення миротворчих місій $\mathrm{OOH}^{13}$.

Перша миротворча місія ООН, наділена повноваженнями 3 розділення воюючих сторін, тривала 3 1956 р. до 1967 р. Мандат миротворчих сил передбачав згоду сторони на їх перебування. I 16 травня 1967 р. Сгипет звернувся з вимогою вивести зі своєї території миротворців ООН. 17 червня останній миротворець покинув Синайський півострів ${ }^{14}$.

У 1960 р. було розгорнуто першу великомасштабну місію - Операцію ООН в Конго, чисельність якої в піковий період становила до 20 тис. осіб. Досвід цієї операції показав небезпечність місій щодо стабілізації ситуації у регіоні охопленому війною - 250 миротворців загинули при виконанні повноважень, у тому числі і Генеральний секретар Даг Хаммаршельд.

У 1960-ті та 1970-ті рp. ООН започаткувала короткострокові місії в Домініканській республіці - Місія Представника Генерального секретаря в Домініканській Республіці, в західній частині Нової Гвінеї (Західний Іріан) - Сили безпеки ООН в Західній Новій Гвінеї, та Смені - Місія ООН зі спостереження в Смені, а також приступила до довгострокового розгортання на Кіпрі - Збройні сили ООН на Кіпрі, і на Близькому Сході - Другі надзвичайні збройні сили ООН, Сили ООН зі спостереження за роз'єднанням та тимчасові сили ООН в Лівані.

У 1988 р. миротворці були удостоєні Нобелівської премії миру за важливий вклад у реалізацію одного 3 основних принципів ООН 15,16 .

У своїй промові на 43-й сесії Генеральної Асамблеї ООН 7 грудня 1988 р. Михайло Горбачов оголосив про скорочення чисельності радянських збройних сил і виведення низки військових підрозділів зі Східної Європи. Він також висловив бажання надати ООН важливішої ролі щодо міжнародного врегулювання збройних конфліктів. Саме ця промова ознаменувала кінець «холодної війни».

У 1989 р. створено три нові місії: Контрольна місія ООН у Анголі в січні, Група ООН щодо надання допомоги в перехідний період у Намібії (UNTAG) у квітні і Група воєнних спостерігачів ООН у Центральній Америці в листопаді. Операція в Намібії дала поштовх до створення нових багатофункціональних місій ООН, кількість яких 31991 р. продовжувала зростати. Операція в Намібії дала поштовх до створення нових багатофункціональних місій ООН, кількість яких з 1991 р. продовжувала збільшуватися, і які перетворилися на операції з підтримання миру ${ }^{17}$.

Попри стабілізацію ситуації багатофункціональна місія виконує різноманітні й інші завдання, такі як репатріація біженців, організація виборів та спостереження за їх проведенням. Так роль ООН та їі миротвор- 
чої діяльності еволюціонувала від миротворчості та спостережних операцій з примирення до операцій із побудови миру. Уперше з часів операції в Конго ООН взяла на себе місію зі складним політичним мандатом і успішно їі виконала. Більше того, місія у Намібії вважається однією із небагатьох успішних операцій ООН або, у крайньому разі, першою успішною ії операцією.

Після закінчення «холодної війни» стратегічний контекст миротворчої діяльності ООН кардинально змінився - від «традиційних» операцій ООН перейшла до «багатофункціональних», завдання яких полягали передусім у тому, щоб забезпечити виконання мирних домовленостей і надати допомогу у формуванні основ для стійкого миру. Також змінився і характер самих конфліктів, якщо на початках миротворчі сили використовувалися для врегулювання міждержавних конфліктів, то поступово вони все більше почали залучатися до внутрішньодержавних конфліктів та громадянських воєн. Окрім того, змінився склад самих миротворчих місій, військовий персонал залишився, але значно збільшилася кількість різноманітних спеціалістів (адміністратори, спостерігачі на виборах, сапери і т.д.) $)^{18}$.

Також після «холодної війни» різко зросла кількість операцій з підтримання миру. У період з 1989 р. по 1994 р. Рада Безпеки санкціонувала 20 нових операцій, що сприяло збільшенню кількості миротворців з 11 тисяч до 75 тисяч.

Після успішного вручання сил міжнародної коаліції після окупації Кувейту Іраком у 1991 р. американський президент Джордж Буш-старший оголосив про створення нового світового порядку, який грунтувався на трьох основних принципах:

- відмова від застосування військової сили з метою агресії;

- сприяння колективній безпеці;

- співпраця провідних держав світу.

В основі цієї концепції лежала ООН, і 31 січня 1992 р. члени Ради Безпеки звернулися до Генерального секретаря Бутроса Бутроса Галі з проханням підготувати документ, який би дав можливість підсилити миротворчий потенціал ООН. «Повістку дня для миру», як його назвали, було опубліковано 17 червня 1992 р.

Концепція щодо забезпечення миру відрізнялася від «традиційної» миротворчості Дага Хаммершельда. Передусім це стосувалося згоди всіх заінтересованих сторін на розгортання миротворчої місії. «Підтримання миру - це забезпечення присутності ООН у конкретному районі, що до цього часу здійснювалося за згодою всіх заінтересованих осіб», зазначалося в «Повістці»19. Таким чином непрямо робилася вказівка, що місія може бути розгорнута без згоди держави, де відбувається конфлікт ${ }^{20}$. А це фактично суперечило принципу суверенної рівності держав.

Наступні нововведення були у п. п. 43 і 44 «Повістки». У першому з них зазначалося, що застосування сили військами ООН має важливе значення для авторитету організації в тих випадках, коли мирні засоби не дали результату, що порушує іще один основоположний принцип міжнародного права - незастосування сили та погрози силою. А у п. 44 Бутрос Галі пропонував створити підрозділи для примусу до миру, які б стали інструментом, який змушував би виконувати рішення Ради Безпеки у тих випадках, коли це виходить за межі повноважень миротворчих місій щодо примусу до миру.

У середині 1990-х рр. місії було розгорнуто у Югославії (Сили ООН з охорони), Руанді (Місія ООН з надання допомоги Руанді) та Сомалі (Операція ООН в Сомалі). Ці місії жорстко розкритикували. Миротворці стикнулися з ситуацією, коли сторони не дотримувалися мирних угод чи коли миротворці не отримували належних ресурсів чи політичної підтримки. Кількість жертв серед мирного населення продовжувала зростати, не припинялися бойові дії. Напевно, тут чи не вперше постало питання про відповідальність місій.

У «Додатку до Повістки», прийнятому в січні 1995 р., тональність Генерального секретаря змінилася, і було акцентовано увагу на «внутрішніх конфліктах», дотриманні трьох основних принципів миротворчої діяльності, а також зазначено різницю між підтримкою миру і примусом до миру, фактично, було враховано досвід Руанди, Сомалі та Боснії.

Після невдач у квітні 1999 р. чисельність миротворців зменшилася з 69 тисяч до 12 тисяч21. Рада Безпеки обмежила розгортання нових місій, а 16 грудня 1999 р. Генеральний секретар Кофі Ананн доручив провести незалежне розслідування діяльності ООН в період геноциду в Руанді 1994 р.22 і на прохання Генеральної Асамблеї 15 листопада 1999 р. надав загальну оцінку подій 1993-1995 р. у Серебрениці в колишній Югославії23.

Тим часом миротворці продовжували здійснювати операції на Близькому Сході, в Азії та на Кіпрі.

Призупинення здійснення миротворчих місій було короткостроковим і уже 10 червня 1999 р. Рада Безпеки доручила Генеральному секретарю забезпечити присутність міжнародного цивільного персоналу в Косово у вигляді Місії ООН у справах тимчасової адміністрації в Косово, 22 жовтня - створити Місію ООН в С'єрра-Леоне, 25 жовтня - розвернути тимчасову адміністрацію ООН у Східному Тиморі, а 30 листопада створити Місію ООН у Демократичній Республіці Конго 24.

Відновлення місій ООН показало, що миротворчість стала постійним інститутом міжнародних відносин.

Враховуючи всі недоліки та проблеми, які виникали під час здійснення миротворчих місії протягом півстоліття, у 2000 р. ООН розпочала реформування миротворчого механізму, яке триває і досі 25 .

3 травня 2010 р. вперше від початку створення миротворчі сили зменшили, а не збільшили свій контингент.

Загалом ООН організувала 71 мирну місію з 1948 р., 14 з яких реалізуються сьогодні. Понад 98 тисяч осіб зі 122 країн світу брали участь у їх здійсненні станом на вересень 2019 р., а бюджет миротворчих операцій на період з 1 липня 2018 р. по 30 червня 2019 р. становив приблизно 6,69 млрд дол. За весь період 
миротворчої діяльності загинуло майже 4 тисячі миротворців (Global peacekeeping data/ https://peacekeeping.un.org/ru/data).

У 1987 р. здійснювалося п’ять мирних операцій, а в 1993 р. їх кількість сягнула 19, у 1995 р. - $20^{26}$. У 2019 р. здійснювалося 14 миротворчих місій 27 . При цьому не всі миротворчі операції здійснюються лише ООН. У період 2004-2013 рр. до стабілізації конфлікту залучалися регіональні організації та ситуативні альянси (як у випадку місій у ЦАР, Чаді і Дарфурі) ${ }^{28}$.

У вересні 2017 р. перед початком 72-ї сесії Генеральної Асамблеї ООН, РБ ООН прийняв резолюцію S/RES/2378 (2017), де наголошується на необхідності «підвищення рівня підзвітності, прозорості, ефективності та результативності операцій $\mathrm{OOH}$ з підтримання миру» ${ }^{29}$. Виходячи 3 положень резолюції, можна зробити висновок, що підвищення ефективності миротворчої діяльності ООН планується досягнути за допомогою покращення планування місій, збільшення числа доступних ООН спеціальних сил і засобів, допоміжних, інженерно-технічних, медичних підрозділів і підрозділів швидкого розгортання, а також підвищення якості підготовки військовослужбовців. ООН визначає найбільш важливі умови успіху операцій з підтримки миру, які повинні гуртуватися на принципах злагоди, неупередженості та незастосування сили за винятком випадків самооборони і захисту мандата; являти собою легітимну і авторитетну структуру, зокрема в очах місцевого населення; сприяти активному залученню в мирний процес приймаючої країни на місцевому та національному рівнях.

Висновки. Миротворча діяльність ООН, яка починалася як тимчасові спостережні місії, виявилася грандіозним проєктом із підтримки миру та безпеки, який триває вже понад півстоліття. Були невдачі та перемоги, але миротворча діяльність довела необхідність свого існування. Вона стала унікальним прикладом глобальної співпраці як основних органів ООН, таких як Генеральна Асамблея, Рада Безпеки, Секретаріат; так і держав, як тих, що надають військові та поліцейські контингенти, так і тих, що приймають місії.

Із 1948 р. $з$ перших спостережних місій і до багатосторонніх та багатофункціональних миротворчих місій з побудови миру миротворча діяльність ОООН значно еволюціонувала і стала набагато ефективнішою, проте надалі існують проблеми щодо легітимності місій $\mathrm{OOH}$, порушення прав людини та інші. Процес реформування миротворчої діяльності ООН триває.

1 Устав Организации Объединённых Наций и Устав Международного Суда 1945 г. URL: https://zakon.rada.gov.ua/laws/ show/995_010\#Text (дата звернення: 17.12.2020).

2 S/RES/50 (1948). Calling for a cessation of hostilities in Palestine. URL: https://digitallibrary.un.org/search?ln=en\&cc=Resolu tions + and + Decisions $\& p=\% 22 \mathrm{UN}+$ Truce + Supervision + Organization $+\mathrm{in}+$ Palestine $\% 22+\mathrm{OR}+\mathrm{UNTSO} \& \mathrm{f}=\& \mathrm{rm}=\& \ln =\mathrm{en} \& \mathrm{sf}=\mathrm{year} \& \mathrm{so}=$ $\mathrm{d} \& \mathrm{rg}=50 \& \mathrm{c}=$ Resolutions $+\mathrm{and}+$ Decisions $\& \mathrm{c}=\& \mathrm{of}=\mathrm{hb} \& \mathrm{fti}=0 \& \mathrm{fct} \quad 3=1948 \& \mathrm{fti}=0$ (дата звернення: 17.12.2020).

3 История миротворческих операций. URL: https://peacekeeping.un.org/ru/our-history/ (дата звернення: 17.12.2020).

4 Операции ООН по поддержанию мира: ОНВУП - фактологический бюллетень. Организация Объединенных Наций. URL: https://peacekeeping.un.org/ru/mission/untso (дата звернення: 17.12.2020).

5 Операции ООН по поддержанию мира: ОНВУП - фактологический бюллетень. Организация Объединенных Наций. URL: https://peacekeeping.un.org/ru/mission/untso (дата звернення: 17.12.2020).

6 ГВНООНИП - ФАКТОЛОГИЧЕСКИЙ БЮЛЛЕТЕНЬ. URL: https://peacekeeping.un.org/ru/mission/unmogip (дата звернення: 17.12.2020).

7 Diehl P. F. First United Nations Emergency Force (UNEF I). The Oxford Handbook of United Nations Peacekeeping Operations. Joachim A. Koops, Thierry Tardy, Norrie MacQueen, and Paul D. Williams (Eds.). Oxford, UK: Oxford University Press, 2015.

8 Атто Рональд. От миротворчества к миростроительству: эволюция роли Организации Объединенных Наций в операциях в пользу мира. Международный журнал Красного Креста. 2013. 95 (891/892). Избранные статьи из номера: «Multinational operations and the law». C. 11.

${ }^{9}$ Hatto R. From peacekeeping to peacebuilding: the evolution of the role of the United Nations in peace operations. International Review of the Red Cross. 2013. Vol. 95. P. 501-505.

${ }^{10} \mathrm{~A} / \mathrm{RES} / 1000$. Resolution 1000 (ES-I). URL: https://unispal.un.org/DPA/DPR/unispal.nsf/0/4357C71ACD47F4AF852560DF 006762D9 (дата звернення: 17.12.2020).

11 Mays T. M. Historical Dictionary of Multinational Peacekeeping. 2nd Edition. The Scarecrow Press, 2004.

12 Hatto R. From peacekeeping to peacebuilding: the evolution of the role of the United Nations in peace operations. International Review of the Red Cross. 2013. Vol. 95. P. 501-505.

13 Атто Рональд. От миротворчества к миростроительству: эволюция роли Организации Объединенных Наций в операциях в пользу мира. Международный журнал Красного Креста. 2013. 95 (891/892). Избранные статьи из номера: «Multinational operations and the law». C. 12.

${ }^{14}$ Diehl P.F. First United Nations Emergency Force (UNEF I). The Oxford Handbook of United Nations Peacekeeping Operations. Joachim A. Koops, Thierry Tardy, Norrie MacQueen, and Paul D. Williams (Eds.). Oxford, UK: Oxford University Press, 2015.

15 История миротворческих операцій. URL: https://peacekeeping.un.org/ru/our-history (дата звернення: 17.12.2020).

16 Миротворческие силы ОOH. URL: https://www.un.org/ru/sections/nobel-peace-prize/united-nations-peacekeepingforces/index.html (дата звернення: 17.12.2020).

17 Атто Рональд. От миротворчества к миростроительству: эволюция роли Организации Объединенных Наций в операциях в пользу мира. Международный журнал Красного Креста. 2013. 95 (891/892). Избранные статьи из номера: «Multinational operations and the law». C. 16.

18 Лямзин А.В., Еланцева Н.С., Николаев Ю.В. Миротворческие операции ООН: основные направления еволюции. URL: https://cyberleninka.ru/article/n/mirotvorcheskie-operatsii-oon-osnovnye-napravleniya-evolyutsii (дата звернення: 17.12.2020).

19 Повестка дня для мира: превентивная дипломатия, миротворчество и поддержание мира (A/47/277-S/24111). URL: https://www.un.org/peacebuilding/ru/policy-issues-and-partnerships/policy/sg-reports (дата звернення: 17.12.2020). 
20 Атто Рональд. От миротворчества к миростроительству: эволюция роли Организации Объединенных Наций в операциях в пользу мира. Международный журнал Красного Креста (2013). 95 (891/892). Избранные статьи из номера: «Мultinational operations and the law». C. 18.

21 Там само. С. 19.

22 S/1999/1297. URL: https://undocs.org/ru/S/1999/1257 (дата звернення: 17.12.2020).

23 Реформа миротворческой деятельности. URL: https://undocs.org/ru/A/54/549 (дата звернення: 17.12.2020).

24 Атто Рональд. От миротворчества к миростроительству: эволюция роли Организации Объединенных Наций в операциях в пользу мира. Международный журнал Красного Креста (2013). 95 (891/892). Избранные статьи из номера: «Multinational operations and the law». C. 20.

25 Реформа миротворческой деятельности. URL: https://undocs.org/ru/A/54/549 (дата звернення: 17.12.2020).

26 Roser M., Nagdy M. Peacekeeping. URL: https://ourworldindata.org/peacekeeping (дата звернення: 17.12.2020).

27 Global peacekeeping data. URL: https://peacekeeping.un.org/ru/data (дата звернення: 17.12.2020).

28 Політико-правові засади миротворчої операції в Донбасі: світовий досвід для України. Наукова записка / Кресін О.В. (кер. авт. кол., наук. ред.), Проценко І.М., Савчук К.О., Стойко О.М. Київ: Інститут держави і права ім. В.М. Корецького НАН України, 2018. С. 66.

${ }^{29}$ S/RES/2378 (2017). URL: https://undocs.org/S/RES/2378(2017) (дата звернення: 17.12.2020).

\section{Резюме}

\section{Жукорська Я.М. Історія виникнення та становлення миротворчої діяльності ООН.}

Миротворча діяльність ООН у традиційному іiі розумінні з'явилася у той час, коли протистояння сторін у холодній війні паралізувало діяльність Ради Безпеки - у 1956 р. під час Суецької кризи.

Для того, щоб розуміти, як еволюціонувала миротворча діяльність від моменту появи і до сьогоднішнього дня, автор пропонує поділити ії історію на періоди.

Миротворча діяльність стала унікальним прикладом глобальної співпраці як основних органів ООН, таких як Генеральна Асамблея, Рада Безпеки, Секретаріат; так і держав, як тих, що надають військові та поліцейські контингенти, так і тих, що приймають місії.

31948 р. миротворча діяльність ООН значно еволюціонувала і стала набагато ефективнішою, проте надалі існують проблеми щодо легітимності місій ООН, порушення прав людини та інші.

Ключові слова: миротворча діяльність, миротворча місія, конфлікт, підтримання миру і безпека, ООН, реформування.

\section{Резюме}

\section{Жукорская Я.М. История возникновения и становления миротворческой деятельности ООН.}

Миротворческая деятельность ООН в традиционном ее понимании появилась в то время, когда противостояние сторон в холодной войне парализовало деятельность Совета Безопасности - в 1956 г. во время Суэцкого кризиса.

Для того, чтобы понимать, как эволюционировала миротворческая деятельность с момента появления и до сегодняшнего дня, автор предлагает разделить ее историю на периоды.

Миротворческая деятельность стала уникальным примером глобального сотрудничества как основных органов ООН, таких как Генеральная Ассамблея, Совет Безопасности, Секретариат; так и государств, как предоставляющих военные и полицейские контингенты, так и принимающих миссии.

С 1948 г. миротворческая деятельность ООН значительно эволюционировала и стала намного эффективнее, однако в дальнейшем существуют проблемы легитимности миссий $\mathrm{OOH}$, нарушения прав человека и другие.

Ключевые слова: миротворческая деятельность, миротворческая миссия, конфликт, поддержание мира и безопасности, $\mathrm{OOH}$, реформирование.

\section{Summary}

Yaryna Zhukorska. The emergence and development of UN peacekeeping activities.

The first two official UN missions to launch UN peacekeeping operations were the United Nations Truce Supervision Organization (Israel) and the United Nations Military Observer Group in India and Pakistan.

The UN's peacekeeping activities, in its traditional sense, came at a time when confrontation between the parties to the Cold War paralyzed the Security Council in 1956 during the Suez Crisis.

In order to understand how peacekeeping has evolved from its inception to the present day, as well as to be able to assess how its effectiveness has grown, the author proposes to divide the history of peacekeeping missions into periods.

In 1987, 5 peacekeeping operations were carried out, and in 1993 their number reached 19, in 1995 - 20. In 2019 - 14 peacekeeping missions were carried out. However, not all peacekeeping operations are carried out only by the UN. Between 2004 and 2013 , regional organizations and situational alliances were involved in stabilizing the conflict (as in the case of the CAR, Chad and Darfur missions).

Peacekeeping has become a unique example of global cooperation as a major UN body, such as the General Assembly, the Security Council, the Secretariat; and States, both those providing military and police contingents and those receiving missions.

Throughout its history, there have been setbacks and victories, but peacekeeping has proved the necessity of its existence. It has become a unique example of global cooperation as a major UN body, such as the General Assembly, the Security Council, the Secretariat; and States, both those providing military and police contingents and those receiving missions.

Given all the shortcomings and problems that have arisen during peacekeeping missions for half a century, in 2000 the UN began reforming the peacekeeping mechanism, which continues to this day.

Since 1948, UN peacekeeping has evolved significantly and become much more effective, but there are still problems with the legitimacy of UN missions, human rights violations and others.

Key words: peacekeeping, peacekeeping mission, conflict, peacekeeping and security, UN, reforming. 